\title{
THE USE OF EPINEPHRINE IN THE PRESENCE OF HALOTHANE IN CHILDREN
}

\author{
ANthony P. Melgrave, M.B., B.S.
}

SINCE EARLY 1965, we have given three hundred or more anaesthetics a year to children at the Alberta Children's Hospital, Calgary. The cases presented in this paper are drawn from that experience.

To paraphrase the words of Katz et al., ${ }^{1}$ there is still a widespread belief that the use of epinephrine during halothane anaesthesia in man is contraindicated because of the possibility of dangerous ventricular arrhythmias. Those authors showed that, using care, exogenous epinephrine may be administered with safety, and this is also our belief. Quoting the work of Price et al. ${ }^{2}$ in relation to cyclopropane, Katz suggested that one important point was to avoid hypercapnia. Besides this, Katz made two other points: (a) that the concentrations of epinephrine should be either $1: 100,000(10 \mu \mathrm{g} / \mathrm{ml})$ or $1: 200,000(5 \mu \mathrm{g} / \mathrm{ml})$, and $(b)$ that no more than $10 \mathrm{ml}$ of $1: 100,000(100 \mu \mathrm{g})$ epinephrine should be administered in 10 minutes, or $30 \mathrm{ml}(300 \mu \mathrm{g})$ in an hour to an adult.

It is interesting to note that Andersen and Johansen ${ }^{3}$ even went so far as to produce deep levels of anaesthesia with halothane, and then try to reverse the hypotension thus produced with intravenous catecholamines. They suggest that not more than $10 \mu \mathrm{g} / \mathrm{min}$ be administered ( $2 \mathrm{ml}$ of $1: 200,000 / \mathrm{min}$ ). Since it would appear preferable to avoid carbon dioxide retention, it should be noted that spontaneous respiration under light halothane anaesthesia is unlikely to be accompanied by this problem. ${ }^{4}$

Since the advent of $\beta$-adrenergic blocking agents, we can either use these prophylactically or, better, have them in reserve should dangerous arrhythmias occur, as shown by Johnstone. ${ }^{5}$ The contraindications to the use of this group of drugs must be borne in mind.

As we have gained experience, our technique has altered. At first we used inhalation inductions, with succinylcholine given either intramuscularly or intravenously. Maintenance was either with the Ayre T-system or semi-closed circle absorption, depending on the size of the child. We now use intravenous inductions in almost all cases. There are some children, chiefly between the ages of six months and two years, whose hands are too fat to find veins. Maintenance is mostly with the Ayre T-piece, using a flow of $\mathrm{N}_{2} \mathrm{O} / \mathrm{O}_{2}: 5 / 3$ through a Fluotec ${ }^{\circledR}$, with every attempt made to reduce the concentration to 0.5 per cent by the time of epinephrine injection. Some anaesthetics are occasionally given using either non-rebreathing or semiclosed circle absorption techniques.

Only the usual simple clinical methods of monitoring blood pressure, pulse, and respiration are used, with almost continuous monitoring from just before to several 
minutes after the use of epinephrine. No attempt is made either to control or assist respiration after the effect of the succinylcholine is worn off.

\section{The Surgeons}

Eight surgeons were involved: four are otolaryngologists, one case was handled by an ophthalmologist, and the other three surgeons, who performed most of the operations, are plastic surgeons. They were well aware of the danger of epinephrine and were most co-operative. Table I shows the distribution of cases through all surgeons: $C, D$, and $\mathrm{E}$ are the plastic surgeons; $\boldsymbol{H}$ is an ophthalmologist doing a plastic procedure; the others are the otolaryngologists.

TABLE I

Number of Cases, by Surgeon

\begin{tabular}{ccccccccc}
\hline $\mathrm{C}$ & $\mathrm{D}$ & $\mathrm{E}$ & $\mathrm{A}$ & $\mathrm{B}$ & $\mathrm{F}$ & $\mathrm{G}$ & $\mathrm{H}$ & Total \\
\hline 105 & 53 & 21 & 8 & 2 & 39 & 1 & 1 & 230 \\
\hline
\end{tabular}

\section{The Procedures}

Table II lists all the procedures carried out during the study. The majority were plastic surgery cases and fall chiefly into three age groups: otoplasties, cleft palates, and cleft lips. The remaining tables illustrate these groups and, in particular give details of the commonest otoplasty age group (years five through seven). It will be seen that, in the case of surgeons $C$ and $D$ doing otoplasties, the dose of epinephrine is within the value given by Katz, prorated for weight. Even allowing for the fact that almost all of these are bilateral procedures, surgeon $\mathrm{E}$ tends to top the limit. Surgeon $F$ always tends to reach up to double the limit when doing mastoidectomies, because he always uses 1:100,000 epinephrine; while all the plastic surgeons tend to exceed the limit in pharyngoplasties and cleft palates, and surgeon $\mathrm{E}$ exceeds it in cleft lips as well.

TABLE II

Procedures Performed

\begin{tabular}{lrr}
\hline \hline Submucuous resection & 13 \\
Rhinoplasty & 1 & \\
Tympanotomy & 11 & total \\
Tympano/myringoplasty & 10 & ENT \\
Mastoidectomy & 11 & \\
& & \\
Otoplasty & 109 & \\
Cleft lip & 25 & total \\
Cleft palate & 23 & plastic \\
Cleft lip revisions & 3 & 184 \\
Pharyngoplasty & 8 & \\
Other plastic & 15 & \\
\hline
\end{tabular}

In this list four cleft lip and two cleft palate patients were outside the normal age group; they are not included in Table VII. 
TABLE III

OTOPLASTIES, BY AGE

\begin{tabular}{lrrrrrrrrrrrrr}
\hline Age & 3 & 4 & 5 & 6 & 7 & 8 & 9 & 10 & 11 & 12 & 13 & 14 & 15 \\
\hline No. of cases & 1 & 6 & 16 & 23 & 19 & 10 & 9 & 4 & 7 & 10 & 2 & 1 & 1 \\
\hline
\end{tabular}

Mean age, 7.62 years. Mode, 6 years. Ages $5-7$ account for $53 \%$ of the cases.

TABLE IV

Otoplasties: Values for the Commonest Age Groups

\begin{tabular}{lccc}
\hline \hline Age in years & 5 & 6 & 7 \\
Number of cases & 16 & 23 & 19 \\
Weight range $(\mathrm{lb})$ & $33-57$ & $40-59$ & $40-75$ \\
$\begin{array}{l}\text { Epinephrine: } \\
\text { average dose } \mu \mathrm{g} / \mathrm{lb}\end{array}$ & 0.63 & 0.84 & 0.6 \\
\hline
\end{tabular}

TABLE $V$

Otoplasties in Ages 5-7, By SURgeon

\begin{tabular}{|c|c|c|c|c|}
\hline Surgeon & $\mathrm{c}$ & $\mathrm{D}$ & $\mathbf{E}$ & $x^{*}$ \\
\hline Number of cases & 36 & 18 & 3 & 1 \\
\hline $\begin{array}{l}\text { Dose used up to } \\
\text { volume (ml) } \\
\text { As } 1 / 100,000(\mu \mathrm{g}) \\
\text { As } 1 / 200,000(\mu \mathrm{g})\end{array}$ & $\begin{array}{r}3 \\
30 \\
15\end{array}$ & $\begin{array}{r}7 \\
70 \\
35\end{array}$ & $\begin{array}{r}10 \\
100 \\
50\end{array}$ & \\
\hline
\end{tabular}

Permissible range: $4-10 \mathrm{ml}, 20-50 \mu \mathrm{g}$. There was a gradual change from $1 / 100,000$ to $1 / 200,000$ epinephrine, and both values are shown.

${ }^{*} \mathrm{X}$ is an otolaryngologist.

\section{Otoplasties}

Since by far the largest group of procedures was comprised of otoplasties, we wish to describe this group more closely. Firstly, the doses shown are the totals for the two ears, since almost all of these were bilateral procedures. Secondly, surgeons $C$ and $D$ proceed with the incision immediately after the injection, thus allowing some of the epinephrine to run out of the wound; surgeon E not only tends to use rather large volumes but also tends to wait a little while before cutting. Thirdly. the procedure is initiated by marking and tattooing; we have noticed that the "injury" stimulus of the tattooing produces tachycardia and/or hypertension, which slowly subside during the injection of the epinephrine and later during the incision. It is rare to see tachycardia and/or hypertension as the result of the epinephrine alonc. The changes, when seen, are usually of the order of five to ten points.

\section{Discussion}

It would appear from our small experience that the use of epinephrine in the presence of halothane is safe, using the anaesthetic technique outlined above and with the understanding co-operation of the surgeons concerned. One obviously striking fact is that doses used in pharyngoplasties, cleft palates, and mastoidec- 
TABLE VI

Anaesthesia Techniques: Otoplasties

\begin{tabular}{|c|c|c|c|c|c|c|}
\hline \multirow[b]{3}{*}{$\begin{array}{l}\text { Dose } \\
\text { No. of cases }\end{array}$} & \multicolumn{6}{|c|}{ Mean thiopentone, $109 \mathrm{mg}(200-0)$} \\
\hline & \multicolumn{3}{|c|}{ succinylcholine (mg) } & \multicolumn{3}{|c|}{ technique } \\
\hline & $\begin{array}{l}30 \\
30\end{array}$ & $\begin{array}{l}25 \\
25\end{array}$ & $\begin{array}{r}20 \\
2\end{array}$ & $\begin{array}{c}\operatorname{scCA} \\
13\end{array}$ & $\begin{array}{c}\mathrm{NRB} \\
2\end{array}$ & $\begin{array}{c}\text { Ayre } T \\
43\end{array}$ \\
\hline
\end{tabular}

Premedication was with meperidine $1 \mathrm{mg} / \mathrm{lb}$ to a maximum of $50 \mathrm{mg}$, and with atropine to a maximum of $0.4 \mathrm{mg}$.

TABLE VII

\begin{tabular}{|c|c|c|c|c|c|c|}
\hline \multirow[b]{2}{*}{ Procedure } & \multirow{2}{*}{$\begin{array}{l}\text { No. of } \\
\text { cases }\end{array}$} & \multirow{2}{*}{$\begin{array}{c}\text { Age } \\
\text { (years) }\end{array}$} & \multirow{2}{*}{$\begin{array}{l}\text { Wt range } \\
\text { (lb) }\end{array}$} & \multicolumn{2}{|c|}{ Dosage } & \\
\hline & & & & actual & prorated & \\
\hline Pharyngoplasty & 5 & $5-10$ & $36-60$ & $\begin{array}{c}6-8 \\
30-40\end{array}$ & $\begin{array}{c}5-8 \\
24-40\end{array}$ & $\mathrm{ml}$ \\
\hline Cleft palate & 21 & 1.5 & $20-30$ & $\begin{array}{c}4-7 \\
20-35\end{array}$ & $\begin{array}{c}2.6-4 \\
13-20\end{array}$ & $\mathrm{ml}$ \\
\hline Cleft lip & 21 & $\frac{3-5}{12}$ & $10-20$ & $\begin{array}{l}0.5-1.0 \\
2.5-5\end{array}$ & $\begin{array}{l}1.3-2.6 \\
6.5-13\end{array}$ & $\begin{array}{l}\mathrm{ml} \\
\mu \mathrm{g}\end{array}$ \\
\hline
\end{tabular}

1/200,000 epinephrine was almost invariably used. In cleft lips the prorated dose would not be exceeded even if 1/100,000 epinephrine were used. Some of the "dose" in pharyngoplasties and cleft palates is lost directly into the pharynx by dripping.

tomies exceed the prorated values allowable. We suggest that children may well be far more tolerant of the effects of exogenous epinephrine, injected subcutaneously and with care, than are adults.

\section{SUMMARY}

A series of 230 cases of children who received epinephrine by subcutaneous injection during halothane anaesthesia is presented. Almost half of these cases were bilateral otoplasties. Plastic surgery procedures constituted three quarters of all cases. Epinephrine in local anaesthetic solution was in a concentration of either $1: 100,000(10 \mu \mathrm{g} / \mathrm{ml})$ or $1: 200,000(5 \mu \mathrm{g} / \mathrm{ml})$. Doses prorated from the allowable dose based on adult studies ( $100 \mu \mathrm{g} / 150$ pounds body weight) were likely to be exceeded in pharyngoplasties, cleft palates, and mastoidectomies. The anaesthesia maintenance technique most commonly used was Ayre's T-piece with a flow of $5 \mathrm{~L}$ of nitrous oxide to $3 \mathrm{~L}$ of oxygen and 0.5 per cent halothane, in an attempt to avoid hypercapnia during spontaneous ventilation. The technique of marking and tattooing by the surgeon, in otoplasties, not uncommonly resulted in either mild tachycardia or hypertension, or both. These appeared to subside during the injection of the epinephrine which followed. It is suggested that perhaps children may be more tolerant of exogenous epinephrine injected subcutaneously than are adults.

However, the explanation might be quite simple. As an example, the latest study 
of Walts and Dillon ${ }^{6}$ suggests that if dose per unit body weight, rather than the newer concept of dose per unit body area, is used in translating adult doses down to children, then the children will receive less of the drug than they actually require or can tolerate. This present study was based on dose for weight.

\section{RÉSUMÉ}

Nous présentons une série de 230 cas d'enfants qui ont reçu de l'épinéphrine en injection sous cutanée au cours d'une anesthésie à l'halothane. Presque la moitié de ces cas ont consisté en otoplasties bilatérales. Soixante-quinze pour cent de tous les cas étaient de la chirurgie plastique. La concentration de l'épinéphrine dans la solution de l'anesthésique local était soit 1:100,000 (10 $\mu \mathrm{g} / \mathrm{ml})$ ou $1: 200,000(5 \mu \mathrm{g} / \mathrm{ml})$. Si l'on détermine la dose permise depuis les études chez les adultes ( $100 \mu \mathrm{g} / 150$ livres poids), la dose autait été dépassée dans les cas de pharyngoplastie, de bec de lièvre et de mastoïdectomies. La technique la plus fréquente pour le maintien a été le tube en $\mathrm{T}$ de Ayre avec un débit de cinq litres de $\mathrm{N}_{2} \mathrm{O}$, trois litres $\mathrm{d}^{\prime} \mathrm{O}_{2}$ et 0.5 pour cent d'halothane, visant à éviter l'hypercapnie en présence de ventilation spontanée. La technique chirurgicale d'inscrire des marques, dans les cas d'otoplasties, a produit assez souvent soit une tachycardie soit une hypertension soit les deux ensemble. L'injection d'épinéphrine qui suit le marquage fait disparaître l'une et l'autre. Cela nous fait croire que les enfants tolèrent peut-être mieux que les adultes l'épinéphrine exogène injectée par voie sous cutanée. Toutefois l'explication pourrait être bien simple. Ainsi, la dernière étude de Waltz et Dillon's suggère que si l'on emploie la dose par rapport à l'unité de poids plutôt que la nouvelle conception de la dose par unité de surface corporelle en transposant les doses pour adultes en doses pour les enfants, les enfants recevront alors une quantité inférieure à celle dont ils ont besoin ou à celle qu'ils peuvent tolérer. L'article-ci, est fait sur la base de dose/poids.

\section{REFERENCES}

1. Katz, R. L.; Matteo, R. S.; \& Papper, E. M. The Injection of Epinephrine during Anesthesia: 2. Halothane. Anesthesiology. 23: 597 (1962).

2. Pruce, H. L.; Lune, A. A.; Jones, R. E.; Pruce, M. L.; \& Linde, H. W. Cyclopropane Anaesthesia: II. Epinephrine and Norepinephrine in Initiation of Ventricular Arrhythmias by Carbon Dioxide Inhalation. Anesthesiology. 19: 619 (1958).

3. Andersen, N. \& Johansen, S. H. Incidence of Catecholamine Induced Arrhythmias during Halothane Anesthesia. Anesthesiology. 24: 51 (1963).

4. Devine, J. C.; Hamiton, W. K.; \& Pittinger, C. B. Respiratory Studies in Man during Halothane Anesthesia. Anesthesiology. 19: 11 (1958).

5. Johnstone, M. Propranolol (Inderal) during Halothane Anaesthesia. Brit. J. Anaesth. 38: 516 (1966).

6. Walts, L. F. \& Dillon, J. B. The Response of Newborns to Succinylcholine and d-Tubocurarine. Anesthesiology. 35: 31 (1969). 